\title{
Plant Density and Yield Component of Haricot Bean (Phaseolus vulgaris L.)
}

\author{
Gebremedhin Welu Teklu \\ College of Agriculture \& Environmental Science, Adigrat University, Adigrat, Ethiopia, P.O.BOX: 50
}

\begin{abstract}
Haricot bean (phaseolus vulgaris L.) is among the five pulse crops predominantly grown in Ethiopia. The experiment was conducted to determine the effect of plant density on yield components of haricot bean in randomized complete block design with three replications. The Data collected for Plant height, Number of branches per plant, Number of leaves per plant and Stem thickness were analyzed using analysis of variance (ANOVA). The analysis of variance showed significantly ( $p \leq 0.05)$ different for number of branches per plant, number of leaves per plant and stem thickness whereas non significant $(p \geq 0.05)$ different for plant height. The second plot with below the recommended density or twelve (12) plants per plot was contain large stem thickness, shorter plant height, more broad and dark green leaf as compared to treatment one and three whereas the third plot with above the recommended density or sixty (60) plant per plot was contain small stem thickness, longer plant height, small leaf number and medium number of branches as compared to others.
\end{abstract}

Keywords: ANOVA, Density, phaseolus vulgaris, RCBD, yield components

\section{Introduction}

Haricot bean (phaseolus vulgaris L.) is among the five pulse crops predominantly grown in Ethiopia. These are faba bean, chick pea, field pea, lentils and haricot bean. These pulses together comprise about $13 \%$ of the total cropped area (Habtu 1987). It is an annual pulse crop with considerable variation in habit, vegetative characters, flower color and the size, shape and color of the pods and seeds (Onwueme \& Sinha 1991).

It is one of the lowland pulse crops produced in the hot regions in equatorial tropics from $500-1500 \mathrm{~m}$. But very good crops can also be obtained in the low land with the right cultivars. In such areas climbing varieties should be grown. In dry seasons and sub humid areas dwarf or bush varieties may also be grown but in humid climates bush cultivars are very prone to fungal and bacterial disease i.e. anthracnose, leaf rot and bacterial blights because of their proximity to soil splash and their denser foliage. In addition well adopted climbing varieties will yield much better than dwarf under any conditions and are more suitable for intensive market farms (willianas \& zool 2005).

In Ethiopia haricot bean is grown as rotation crops with cereals. It has been known as an export crop for long period contributing to the foreign exchange earnings. It is also grown as a food crop haricot bean is consumed in traditional dishes. The crop produced highly for consumptions than export. Dry beans are mostly prepared as nifro (boiled grain), mixed with sorghum or maize and wet (local soup) and also with kocho. Fresh beans (mature whole non dried grain) are popular for their taste and crack ability. It compliments cereals and other stable foods in the diet (Adamu et al. 2005). The current national average yield of haricot bean is 12.62 quintals per hectare. The total area and total productions is estimated to be $366,876.94$ hectares and 4,630,084.90 quintals respectively (CSA 2013)

Haricot bean is an important pulse crop distributed and grown in different parts of Ethiopia depending on climatic and socio-economic factors. In southern parts of the country, it is also widely distributed and grown by farmers for various uses (Tenaw 1990). Its grain is used for food and making money, whereas it's by product including its stalk and leaves is used for fire wood and feed .moreover, since it is short maturing and has moderate drought tolerance. It is used as the main or the only food in short growing seasons and poor annual harvest areas. Thus it plays a vital role in farmers risk aversion strategies (Adamu et al. 2005).

Ethiopian farmers, in general, use lower seed rate than research recommendations which result in lower grain yields (Ali et al. 2003). The seed yield of bean is the result of many plant growth processes which ultimately influence the yield components such as pods/plant, seeds/pod, and unit weight of seed. The highest seed yields were obtained when all the above got maximized (Tessbo et al. 2004).

Crop plant should have to cover the soil as early as possible to intercept maximum sunlight to produce high dry matter as the intercepted solar radiation and dry matter production are directly related as plant density increase the amount of dry matter in vegetative part also increases. By maintaining optimum plant population under suitable environment it is possible to get more than ten quintals per hectare (Adamu et al. 2005). Therefore it is important to determine the optimum population density of haricot bean at shonga site with the following objective:

- To evaluate the effect of density (plant population) on yield component of haricot bean

\section{Materials and Method}

\section{Description of the Study Area}

The study was conducted in 2012 at Bench-Maji zone of the southern nation, nationalities and people regional state (SNNPRS) around Mizan-Aman district particularly at Shonga site of Mizan-Tepi University College of agriculture and natural resource. It located at altitude of $35^{\circ} 34^{\prime} 6.34$ and longitude of $6^{0} 58^{\prime} 34^{\prime \prime} \mathrm{N}$ and at altitude of 1350 meter above sea level and about $561 \mathrm{~km}$ from Addis Ababa and $842 \mathrm{~km}$

Volume 5 Issue 6, June 2016 www.ijsr.net 


\section{International Journal of Science and Research (IJSR) \\ ISSN (Online): 2319-7064 \\ Index Copernicus Value (2013): 6.14 | Impact Factor (2015): 6.391}

from regional capital Hawasa. The soil of the area is generally red brown with scattered tract of red colour soil. The annual rain fall is from 1256 to $2000 \mathrm{~mm}$ and the annual average temperature range from 20 to $40^{\circ} \mathrm{c}$. The area is wet moist the year with relatively dry season in January, February, March and May the main rain occurs in April and from June to September.

\section{Experimental Material}

Three level of variety called Dinkinesh was used as experimental material (Table 1) to determine the optimum population density in the area.

Table 1: Treatment combinations in the experiment at Shonga during 2012

\begin{tabular}{|l|l|l|}
\hline Treatment & Plant density & Rank \\
\hline T1 & Thirty seed per plot & 2 \\
\hline T2 & Twelve seed per plot & 3 \\
\hline T3 & Sixty seed per plot & 1 \\
\hline
\end{tabular}

\section{Experimental design}

Randomized complete block design (RCBD) with three replications was used. Each experimental plot have three rows of $5.6 \mathrm{~m}$ long spaced $40 \mathrm{~cm}$ a part with a plot area of $1.2 \mathrm{~m}(1 \mathrm{mx} 1.2 \mathrm{~m}) 1 \mathrm{~m}$ distance between replications and 0.5 $\mathrm{m}$ between plots. A spacing of $40 \mathrm{~cm} \times 10 \mathrm{~cm}, 40 \mathrm{~cm} \times 25 \mathrm{~cm}$ and $40 \mathrm{~cm} \times 5 \mathrm{~cm}$ were used for planting the seed. All necessary agronomic practiced was done uniformly as per the recommended.

\section{Data Collection}

Data were collected from a sample of five plants at random from each plot to measure the following growth parameters: Plant height $(\mathrm{cm})$ : the height of the main stem from ground level to the tip of the plant. Number of branches per plant: was determined by counting the number of primary reproductive branches. Number of leaves per plant: by counting the number of leaves per plant and Stem thickness. The data on each parameter was collected from the central rows in each plot. Plants of each end of plant were border rows plants and hence the data was not recorded. Data for plant height, and stem thickness was collected by using tape meter.

\section{Data Analysis}

Data were analyzed statistically using analysis of variance (ANOVA) according to Gomez and Gomez (1984) procedure for a randomized complete block design using SAS software. The differences of means were identified by LSD test.

\section{Results}

From this experiment it can be observed that intra-specific competition among the haricot bean plants and it influences the full expression of the attributes. There was a difference among each treatment which is significantly different and non- significantly different as a result.

\section{Stem thickness}

The experiment was showed a significantly $(p \leq 0.05)$ different between treatments for stem thickness (table 2). The stem thickness was strong and large as plant population decreases because the plant grown slowly since there was low intra-specific competition as a result of low plant density. The larger the spacing $(40 \mathrm{~cm} \times 25 \mathrm{~cm})$ the largest stem thickness $(0.67 \mathrm{~cm})$ whereas the lowest stem thickness $(0.48 \mathrm{~cm})$ was recorded at treatment three with a space of $40 \mathrm{cmX} 5 \mathrm{~cm}$ and a grand mean $0.559 \mathrm{~cm}$ was observed. There is no significant difference between treatment one and treatment three which was $40 \mathrm{~cm} \times 10 \mathrm{~cm}$ with the stem thickness $0.52 \mathrm{~cm}$ and $40 \mathrm{~cm} \times 5 \mathrm{~cm}$ with the stem thickness $0.48 \mathrm{~cm}$ respectively.

\section{Number of branches}

Treatment two $(40 \mathrm{~cm} \times 25 \mathrm{~cm})$ shows the significant $(p \leq 0.05)$ difference and more branch number than treatment one and treatment three with a density of $40 \mathrm{~cm} \times 10 \mathrm{~cm}$ and $40 \mathrm{~cm} x 5 \mathrm{~cm}$ respectively. Treatment one and treatment three were not significantly different and treatment three has more branch number than treatment one (table 2).

Table 2: Mean value of yield related traits haricot bean treatments for the data collected at Shonga during 2012.

\begin{tabular}{|c|c|c|c|c|}
\hline treatment & St & Nob & Nol & Ph \\
\hline T1 & O.52b & $15.667 \mathrm{~b}$ & $34.75 \mathrm{~b}$ & $30.877 \mathrm{a}$ \\
\hline T2 & $0.67 \mathrm{a}$ & $22.333 \mathrm{a}$ & $48.583 \mathrm{a}$ & $27.667 \mathrm{a}$ \\
\hline T3 & O.48b & $16.00 \mathrm{~b}$ & $32.667 \mathrm{~b}$ & $30.667 \mathrm{a}$ \\
\hline Mean & 0.559 & 18 & 38.666 & 29.736 \\
CV (\%) & 13.16 & 14.58 & 9.389 & 11.462 \\
LSD & 0.147 & 5.2438 & 7.2534 & 6.80 \\
\hline
\end{tabular}

Values with the same letter in a column are not significantly different $(p \leq 0.05)$

Where: $\mathrm{T} 1=$ thirty seed per plot, $\mathrm{T} 2=$ twelve seed per plot, T3=sixty seed per plot, Nol=leaf number, $\mathrm{St}=$ stem thickness, $\mathrm{Nob}=$ number of branches, $\mathrm{Ph}=$ plant height, $\mathrm{CV}=$ Coefficient of variance and $\mathrm{LSD}=$ least significant difference

\section{Number of leafs}

As plant population increase number leaf decrease and treatment two which was $40 \mathrm{~cm} \times 25 \mathrm{~cm}$ is significantly $(p \leq 0.05)$ different with the leaf number 48.583 whereas treatment one and treatment three with a spacing of $40 \mathrm{~cm} \times 10 \mathrm{~cm}$ and $40 \mathrm{~cm} \times 5 \mathrm{~cm}$ respectively were not significantly different one another. However treatment one (34.75) was greater leaf number than treatment three (32.667).

\section{Plant Height}

Treatments were not significantly $(p \geq 0.05)$ different; however, as a plant density increase plant height also increase the plant in the plot with $40 \mathrm{~cm} \times 25 \mathrm{~cm}$ has less height than that of plant in the plot with $40 \mathrm{~cm} \times 10 \mathrm{~cm}$ and $40 \mathrm{~cm} \times 5 \mathrm{~cm}$ (table 2). This is due to intra-specific competition for the sunlight.

\section{Discussion}

From this experiment it can be observed that intra-specific competition among the haricot bean plants and it influences the full expression of the attributes. There was a difference among each treatment which is significantly different and non- significantly different as a result.

\section{Volume 5 Issue 6, June 2016 www.ijsr.net}




\section{International Journal of Science and Research (IJSR) \\ ISSN (Online): 2319-7064 \\ Index Copernicus Value (2013): 6.14 | Impact Factor (2015): 6.391}

Competition between component crops for growth limiting factors is regulated by basic morpho-physiological difference and time of sowing of component crops competition for light and other resource is the most common competition under field condition. Intra-specific or interplant competition, is when common recourses are limited for all the plants of a similar species, such as between the established crop plant with a given crop canopy. Individual plant productivity is typically limited by competition for light, water, soil nutrients or competition of each (Buhler \& Hartler 2004). To avoid nutrient competition sufficient spacing between plants and rows is vital to get maximum yield in a given plot of land. Appropriate spacing enables the farmer to keep appropriate plant population in his field. Hence, a farmer can avoid over and less population in a given plot of land which has negative effect on yield (Alemitu 2011).

\section{Stem thickness}

In this experiment the stem thickness was strong and large as plant population decreases because the plant grown slowly since there was low intra-specific competition as a result of low plant density. The larger the spacing the larger stem thickness whereas the lowest stem thickness was observed as the density of population increases. Stem thickness showed inverse relationship with sowing density (Amaducci 2008; Hall et al. 2014). Another report by Van der Werf (1996) indicates that increasing plant density results in thinner stemmed plants. Stem dry weight followed a linear trend for plant spacing and as plant spacing decreased stem dry weight diminished (Jovicich et al. 1998).

\section{Number of branches}

At a close spacing the branches develop less in number than at wider spacing (El Naim et al. 2010). Weber et al. (1966) also found that on soybean, plants produced at highest densities were taller and more sparsely branched. This is similar result to this experiment in which more branch number was observed with a density became less and less. But Ahmed et al. (2010) found that Intra-row spacing had no significant differences in number of branches per plant in cowpea and groundnut at the same year. Lazim \& Nadi (1974) also reported that spacing had no effect on mean number of branches per plant; this may be attributed to the growth habit of the cultivars used.

\section{Number of leafs}

As plant population increase the number leaf decrease whereas the leaf number increases as the number of population decreases throughout the experiment. Studies by (Lazim 1972) also showed that, increasing plant population decreased the number of leaves per plant. In contrast, Ahmed et al. (2010) indicate intra-row spacing had no significant effect on number of leaves per plant. This may be attributed to the growth habit of the cultivars used.

\section{Plant Height}

Even though there was no significantly difference between treatments; plant height incresase as plant density increases. This is due to intra-specific competition for the sunlight. Increment in plant height may be attributed to either an increase in node number or internodes length or both (Ahmed et al. 2010). Dense plant stands leads to reduction in leaf thickness and alters leaf orientation. Dry matter production per unit area increases with increases in plant density up to a limit as in biological yield. When plants are widely spaced vegetative dry matter yields will at first tend to increase with inversing plant density. This indicates that no appreciable competition is occurring between neighboring plants. Plant numbers compensates almost exactly for reduction in the production of individual plant (Girma \& Hunt 1975). Intra-row spacing had no significant effect on plant height at all sampling occasions in haricot bean (Ahmed et al. 2010). Mohamed (2002) also reported that intra-row spacing had no significant effect on most of the growth attributes. Plant density had no significant effect on plant height. The non significant effect of plant density on mean plant height observed may be attributed to the fact that plant spacing has often, but not always, been associated with increased plant height (Ahmed et al. 2010). In the other case Abuzar et al. (2011) reported that due to crowding effect of the plant and higher intra-specific competition for resources plant height decrease as population number increases in maize. This trend explains that as the number of plants increased in a given area the competition among the plants for nutrients uptake and sunlight interception also increased (Sangakkara et al. 2004).

\section{Conclusion}

Plant density has considerable effects on growth rate, development of plant height, number of leaf per plant, stem thickness and number of branches but has better for reduction of the population of weed by occupying the area. Plant with a dense population were grown rapidly high in plant height however as the density increases tiny stem thickness, small leaf number and less number of branches were observed. As a result the level with low number of plants showed good performance for most of the attributes.

\section{References}

[1] Adamu, B., bedru, Deresse, A. (2008). Adopting improved haricot bean varieties in the central Rift valley in Ethiopia.

[2] Ahmed M. E. N., Hagelsheep, A. M., Abdelmuhsin, M. S., Abdalla, A. E. (2010). Effect of Intra-row Spacing on Growth and Yield of Three Cowpea (Vigna unguiculata L. Walp.) Varieties under Rainfed. Research Journal of Agriculture and Biological Sciences 6(5), 623-629

[3] Ahmed, M. E. N., Eldouma, M. A., Abdalla, A. E. (2010). Effect of Weeding Frequencies and Plant Density on the Vegetative Growth Characteristic in Groundnut (Arachis Hypogaea L.) in North Kordofan of Sudan. International Journal of Applied Biology and Pharmaceutical Technology Volume: I: Issue-3, Page: 1188

[4] Alemitu, M. A. (2011). Factors Affecting Adoption of Improved Haricot Bean Varieties and Associated Agronomic Practices in Dale Woreda, SNNPRS M.Sc. Thesis Hawassa University, Hawassa, Ethiopia

[5] Ali, K., Gemechu, A.S, Beniwal, M.R., Makkouk, S., and Halila, M. (2003). Food and forage legumes of Ethiopia; Progress and prospects on food and forage

\section{Volume 5 Issue 6, June 2016 www.ijsr.net}


legume proceeding of the workshop, 22-26 September 2003, Addis Ababa, Ethiopia.

[6] Abuzar, M. R., Sadozai, G. U., Baloch, M. S., Baloch, A. A., Shah, I. H., Javaid, T., Hussain, N. (2011) Effect of Plant Population Densities on Yield of Maize. Journal of Animal \& Plant Sciences 21(4), Page: 692695

[7] Amaducci, S, Zatta A., Pelatti, F, Venturi, G. (2008). Influence of agronomic factors on yield and quality of hemp (Cannabis sativa L.) fibre and implication for an innovative production system. Field Crops Research 107, 161-169.

[8] CSA (2013) Central Statistical Authority. Area and Production of crops (Private peasant holdings, Maher season).Statistical Bulletin Addis Ababa Ethiopia.

[9] Girma and hunt (1975) competition among plant density

[10] Habtamu Assefa, 1987.Ethiopian journal of agricultural science volume ix No-1.

[11] Hall, J., Bhattarai, S. P., Midmore D. J. (2014). Effect of industrial hemp (Cannabis sativa $\mathrm{L}$ ) planting density on weed suppression, crop growth, physiological responses, and fibre yield in the subtropics. Renewable Bioresources 2052-6237-2-1

[12] Jovicich, E., Cantliffe, D. J., Hochmuth, G. J. (1998). Plant density and shoot pruning on yield and quality of a summer greenhouse sweet pepper crop in Northcentral Florida

[13]Lazim, M.H. (1972). Haricot bean variety and spacing experiment. Annual report, Hudaeiba Resersh Station, Damer, Sudan.

[14] Lazim, M., Nadi, A.H. (1974). Growth and yield of irrigated sesame 1. Effect of population and variety on vegetative growth. Experiment Agriculture 10, 65-69.

[15] Mohamed, L.Z. (2002). The effect of intra-row spacing and starter nitrogen fertilizer on growth and yield of cowpea (Vigna unguiculata L. walp). M. Sc. Thesis, University of Khartoum, Sudan.

[16] Onwueme, I.C., Sinha, T.D. (1991). "Field crop production in tropical Africa", Technical Center for Agriculture and Rural Co-operation.

[17] Sangakkara, U. R., Bandaranayake, P. S. R. D., Gajanayake, J. N., Stamp, P. (2004). Plant populations and yield of rainfed maize grown in wet and dry seasons of the tropics. Maydica. 49: 83-88.

[18] Tenaw Workayehu (1990). "Review of Agronomic Studies on Haricot Bean in the Southern Zone of Ethiopia", Research on Haricot Bean in Ethiopia: an Assessment of Status, Progress, Priorities and Strategies, Proceedings of a National Workshop held in Addis Ababa, 1-3 October 1990,114 p.

[19] Van der Werf, H. M. G, Mathijssen, E. W. J. M, Haverkort, A. J. (1996). Crop physiology of Cannabis sativa L.: A simulation study of potential yield of hemp in Northwest Europe. In: RANALLI, P. (ed.) Advances in Hemp Research. New York: Food Products Press.

[20] Weber, C.R., Shibles, R.M., Byth, D.E. (1966). Effect of plant population and row spacing on Soybean development and production. American Society of Agronomy Journal 58, 99-102.

[21] Willianas, C.N, and Zool (2005). Vegetation production in the tropics.

Volume 5 Issue 6, June 2016 www.ijsr.net 